\title{
The Colonial Origins of Civil War
}

\author{
Simeon Djankov \\ The World Bank and CEPR \\ Marta Reynal-Querol ${ }^{1}$ \\ Universitat Pompeu Fabra, CEPR, and CESifo
}

May 2007

\begin{abstract}
The dominant hypothesis in the literature that studies conflict is that poverty is the main cause of civil wars. We instead analyze the effect of institutions on civil war, controlling for income per capita. In our set up, institutions are endogenous and colonial origins affect civil wars through their legacy on institutions. Our results indicate that institutions, proxied by the protection of property rights, rule of law and the efficiency of the legal system, are a fundamental cause of civil war. In particular, an improvement in institutions from the median value in the sample to the $75^{\text {th }}$ percentile is associated with a 38 percentage points' reduction in the incidence of civil wars. Moreover, once institutions are included as explaining civil wars, income does not have any effect on civil war, either directly or indirectly.

JEL: 011
\end{abstract}

Key Words: Institutions, Civil wars

\footnotetext{
${ }^{1}$ We are indebted to Daron Acemoglu, Antonio Ciccone, José G.Montalvo, Diego Puga, Marco Runkel and seminar participants at Universitat Pompeu Fabra, University of California Irvine, University of Namur, and CESifo annual conference for their comments.
} 


\section{Introduction}

What causes civil war? To-date, differences in income have received the most attention as the answer. The idea that poverty increases the risk of conflict is stated in the United Nation's Millennium Development Goals: "Poor and hungry societies are much more likely than highincome societies to fall into conflict over scarce vital resources, such as watering holes and arable land. Poverty increases the risks of conflict through multiple paths."2

However, the link between poverty and civil wars is largely untested: only two empirical studies provide some evidence. Fearon and Laitin (2003) finds that lower income per capita increases the likelihood of civil war, alongside other correlates like large populations and mountainous geography. They argue that income per capita is a proxy for the "state's overall financial, administrative, police and military capabilities.” If the government is weak, rebels can expect success. Collier and Hoeffler (2004) finds that income variables, which could proxy some grievances but are perhaps more related to the viability of rebellion, provide considerable explanatory power. Neither study deals with the possibly endogeneity of war to economic stagnation. This is done in Miguel et al. (2004) in a study of 41 African countries. They use rainfall as an instrument for economic growth and find that economic stagnation is strongly related to civil conflict, i.e., civil war is related to changes in income, not the level of income.

There is a larger literature that studies the relationship between political institutions and civil war. Sambanis (2001), Hegre et al. (2001), and Reynal-Querol (2002a,b) find that partial democracies are more prone to civil wars than full democracies and autocracies. Reynal-Querol (2005) tests whether the type of democracy, rather than democracy per se, can explain why some

\footnotetext{
${ }^{2}$ United Nations (2005), p. 6.
} 
countries have civil war and others do not. She finds a negative relationship between the inclusiveness of political institutions and the incidence of civil wars. The rationale is that political inclusiveness increases the opportunity cost of rebellion. ${ }^{3}$

To-date, the development of economic institutions has not been linked to the study of civil wars. In this paper we investigate whether the quality of economic institutions has played a role in sustaining peace. In particular, we test the hypothesis that when governments cannot enforce the law and protect property rights conflict emerges. The idea that strong institutions prevent conflict derives from the theoretical literature of conflict: Haavelmo (1954), Grossman (1994, 1996), Skaperdas (1992, 1996), Garfinkel (1990), Hirshleifer (1995), among others.

This paper is also related to the extensive empirical literature that has investigated the role of institutions in development. Mauro (1995), Knack and Keefer (1995), Hall and Jones (1999), Acemoglu et al. (2001, 2002), Easterly and Levine (2003), Djankov et al. (2002; 2003), Alcala and Ciccone (2004), Dollar and Kraay (2003) and Rodrik (2004), among others, show a positive relationship between institutions and various proxies for development.

Our empirical approach is closely related to this literature. The common idea in the literature is that there are some historical roots that are based on the European influence during colonization that explain institutional development, and that have nothing to do with contemporaneous factors, in our case civil wars. We follow the work of Acemoglu, Johnson and Robinson (2001), who propose a theory of institutional differences among countries colonized by Europeans, based on the role of settler mortality in shaping local institutions. Consistent with

\footnotetext{
${ }^{3}$ The results on the relationship between democracy and civil wars parallel the literature on the relationship between democracy and growth. Barro (1997) and Glaeser et al (2004) find weak effects of political institutions on growth. Persson (2004) shows that the form of democracy, rather than democracy per se, has important consequences for the adoption of structural policies that promote growth.
} 
Acemoglu et al (2001), we also study institutional differences between British colonies and colonies from the other major imperial powers (France, Spain and Portugal).

The results indicate that lack of secure property rights and enforcement of the law is a fundamental cause of civil war. In particular, an improvement in institutions from the median value in the sample to the 75th percentile is associated with a 38 percentage points' reduction in the incidence of civil wars. Moreover, once institutions are included in the regression analysis, income does not have any direct effect on civil war. This suggests that the direct effect of per capita income found in previous literature may have simply captured the effect of institutions. Finally, we find that per capita income does not have an indirect effect on civil war through worsening institutions once we include historical factors as instrument of institutions. This result is in line with the recent findings in Acemoglu et al (2006), where they test the relationship between income and democracy. They show that controlling for factors that simultaneously affect both variables removes the statistical association between income per capita and various measures of democracy. Our findings undermine the emphasis on poverty as a determinant of civil war and indicate that research may concentrate more on institutions than on economic development if we wish to understand the causes of civil war.

Section 2 describes the data. Section 3 details the empirical strategy. Section 4 develops an instrumental variables approach to study the causes of civil wars. Section 5 and 6 provide robustness tests. Section 7 concludes.

\section{Data}

Data on civil wars comes from the Armed Conflict Dataset, a joint project between the Department of Peace and Conflict Studies, Uppsala University and the Center for the Study of Civil War at the 
International Peace Research Institute, Oslo. An armed conflict is defined as a contested incompatibility that concerns government and/or territory where the use of armed force between two parties, of which at least one is the government of a state, results in at least 25 battle-related deaths. We use conflict types 3 and 4, which correspond to civil wars.

Since we do not observe the exact characteristics of institutions that are related with conflict, we need to identify the institutional variables that best capture the lack of contract enforcement and insecure property rights. We start the analysis by using the average protection against expropriation risk. This variable captures the risk of expropriation of private foreign investment by government, and goes from 0 to 10, where a higher score means less risk. This index is the average between 1985 and 1995. This variable, which comes from Acemoglu et al (2001), was originally used by Knack and Keefer (1995). Table 1 lists the ranking of the fifteen countries with the lowest and the highest protection against expropriation risk. The civil war variable indicates whether the country suffered any civil war during the period 1960-2005. All of the fifteen countries with the lowest scores suffered a civil war, while only seven of the fifteen countries with the strongest protection suffered a civil war.

Our second proxy for economic institutions is a measure of law and order. It measures the strength and impartiality of the legal system, and the popular observance of the law. The source for this variable is the International Country Risk Guide (ICRG). The law and order variable can take values from 0 to 6 . Higher numbers indicate a stronger legal system. ${ }^{4}$ Table 2 lists the ranking of the fifteen countries with the weakest law and order system, and the fifteen countries with the strongest legal system. The law and order index is the average of the law and order indicator from

\footnotetext{
${ }^{4}$ Other variables from the ICRG are the quality of bureaucracy and corruption. The results are robust to the use of these variables.
} 
1984 to 1999 . All of the fifteen countries with the lowest scores suffered a civil war, while only four of the fifteen countries with the strongest legal system suffered a civil war.

The rankings here are simply descriptive since they are subject to the endogeneity of institutions. However, they provide some evidence of the correlation between economic institutions and the existence of conflict. In the next section we present a rigorous analysis of the statistical relationship between economic institutions and civil war.

\section{Empirical strategy}

We have a sample of 211 countries among which 113 are ex-colonies. Between 1960 and 2005, 94 countries suffered civil war, 72 of them ex-colonies. Moreover, only 22 of the 96 non ex-colonies suffered a civil war. Our specification is a cross-section of countries. There are other important advantages that favor the use of a cross-section in this type of analysis.

Researchers have used three alternative measures in the study of the causes of civil wars: the onset of civil wars, their incidence and their duration. These analyses are complementary but deal with different sides of the civil war phenomenon. In principle some factors that may affect the onset of a civil war could have no impact on its duration. In a cross-sectional analysis, incidence and onset are the same. The dependent variable is a dummy that has a value of 1 if the country suffered a civil war during the period 1960-2005, and zero otherwise. Finally, we use the per capita income in 1960 to reduce the endogeneity problem between per capita income and civil war.

The explanatory variables follow the basic specifications in the literature on civil war. The size of the population is one common suspect in the explanation of conflict. Collier and Hoeffler (2004) consider that the size of the population is an additional proxy for the benefits of a rebellion since it measures potential labor income taxation. Fearon and Laitin (2003) indicate that a large 
population implies difficulties in controlling what goes on at the local level and increases the number of potential rebels that can be recruited by the insurgents.

The explanatory variables for the core specification of the probability of civil wars includes the log of real GDP per capita in 1960 (lgdp60) and the log of the population in 1960 (lpop60). We calculate the mean of the institutional variable of the period in which data is available. In the case of the ICRG, the period is 1984-1999 and for the protection against expropriation risk we have the average for the 1985-1995 period. We first show some preliminary results using the logit specification, and then we analyze the relationship between institutions and civil war addressing the endogeneity problem between institutions and conflict, using the IV-2SLS approach.

We first present the estimation of a logit model for the probability of civil wars, using a sample of 211 countries. The logit equation is the following: $\operatorname{Prob}\left(\right.$ conflict $\left._{i 60-05}=1\right)=\Lambda\left(\alpha+\beta_{1} \lg d p_{i 60}+\beta_{2}\right.$ lpop $_{i 60}+\beta_{3} a v_{-}$inst $)$, where conflict is a dummy variable that has a value of 1 if the country had a civil war during the period 1960-2005 and zero otherwise, $\alpha$ is a constant, $\operatorname{lgdp}$ is the log of real per capita income in 1960, Ipop is the log of the population of the country in 1960, av_inst is the average of the institutional measure between 1985 and 1995 for the protection against expropriation risk, between 1984 and 1999 for the ICRG law and order measure. The ideal set-up would be to have information on the quality of institutions before 1960, however data are not available for that period. We address the endogeneity issue in the next section.

In column 1 of Table 3 we analyze the effect of the two core variables, population and per capita income on the probability of civil war and find that poor countries and highly populated countries have a higher risk of conflict. In column 2 we include our first proxy for economic institutions, the protection against the risk of expropriation. The results show that countries with 
high protection against expropriation risk have a lower probability of civil wars than countries with low protection. When we include the core variables in civil war regression, in column 3 , this result is maintained, and per capita income loses its effect. In columns 4 and 5, we include the law and order institutional variable. The results indicate that countries with a weak legal system have a higher probability of civil war than countries with efficient courts. In column 5, we include per capita income, population and law and order. We find that per capita income is no longer significant, whereas law and order is still significant.

We next check whether the results are maintained when we control for the inclusion of other variables that have been used in different studies of civil wars. Collier and Hoeffler (2004) point out that the existence of natural resources provides an opportunity for rebellion since these resources can be used to finance war and increases the payoff if victory is achieved. We include variables that capture the percentage of world gold, iron, silver, zinc and oil reserves. Following Fearon and Laitin (2003) mountains are another dimension of opportunity since this terrain could provide a safe haven for rebels. And long distances from the center of the state's power also favors the incidence of civil wars, especially if there is a natural frontier between them, like a sea or other countries. Montalvo and Reynal-Querol (2005a, b) show that ethnic polarization explains the likelihood of conflicts and civil wars. Finally, many authors control for the level of democracy.

We include all these variables together with our core variables in Table 4, columns 1 through 5. In columns 6 to 10 we perform the same exercise but including our institutional variable. As before, the results indicate that once the institutional variable is included, per capita income loses its significant effect on civil wars, while the lack of economic institutions keeps its negative and significant effect. 
In table 5 we perform the same analysis as in table 3 but using the sample of 113 excolonies. The results are similar to the ones obtained using the whole sample. In particular, if we go

from the median of the explanatory variable to the $75^{\text {th }}$ percentile, the probability of suffering a civil war is reduced by 15 percentage points. In all the specifications, economic institutions have the expected effect and sign, and per capita income turns out to be insignificant when included together with economic institutions.

Overall, these results suggest that institutions could matter in explaining conflict, and that they seem to matter more than poverty per se. However, the logit estimation is problematic due to the possibility of reverse causality between economic institutions and civil wars. In the next section we perform the same analysis while considering economic institutions as endogenous.

\section{Instrumental variable approach}

One way of looking at the endogeneity problem is to run an instrumental variable estimation for civil wars disregarding the fact that this is a 0-1 variable that is an IV-2SLS. Angrist (1991) shows, using a Monte Carlo experiment, that if we ignore the fact that the dependent variable is dichotomous and use the instrumental variables approach, the estimates are very close to the average treatment effect obtained using a bivariate probit model. Therefore this approach has sound theoretical support. Moreover, following Angrist and Krueger (2001), the IV-2SLS method is typically preferred even in cases in which the dependent variable is dichotomous.

When using an instrumental variable approach, we need to find an instrument for economic institutions: variables correlated with institutions and uncorrelated with the residual of the regression for civil wars. The work of Acemoglu, Johnson and Robinson (2001), emphasizes the role of European settler mortality rates to estimate the effect of economic institutions on 
development. In places where Europeans faced high mortality rates, they could not settle and were more likely to set up extractive institutions. These institutions persist at present. We also consider differences between British colonies and colonies from the other big imperial powers (French, Spanish and Portuguese colonies). Acemoglu et al (2001) include a dummy for the British and a dummy for the French colonial origin. The other colonial origin was the omitted dummy variable. Since we are not interested in the effect of different colonial powers in the civil law tradition, we aggregate countries into three groups. Col_br is a dummy that has a value of 1 if the country was an old British colony and zero otherwise. The Col_frsppor variable has a value of 1 whether the country was an old colony of France, Spain or Portugal, and zero otherwise. Col_oth is a dummy variable that has a value of 1 whether the country was a colony of the other colonial powers, and zero otherwise. In this aspect, our study is closely related with the studies that emphasize the role of the legal transplantation to explain institutional development as in La Porta et al (1999), Djankov et al. (2002) and Botero et al. (2004), among others, who find significant differences between common law and civil law countries. They argue that as "European powers conquered much of the world, they brought with them their institutions, including their laws. During his war, Napoleon exported the French legal system to Spain, Portugal and Holland. Through colonial conquest, it was transplanted to Latin America, to large parts of Europe and North and West Africa, and part to the Caribbean and Asia. The common law tradition was transplanted by England to the US, Canada, Australia, New Zealand, East Africa, to large parts of Asia, including India, and to parts of the Caribbean”. They conclude that having a tradition of common law or a civil law is a significant determinant of economic institutions today.

We analyze the effect of institutions on civil war, using the log of European settler mortality and common law/civil law dummies. The exclusion restriction implied by our instrumental variable 
regression is that, conditional on the controls included in the regression, settler mortality and colonial origin have no effect on civil wars other than their effect through economic institutions.

$$
\begin{aligned}
& \text { conflict }_{i 60-05}=\alpha+\beta_{1} \lg d p_{i 60}+\beta_{2} \text { lpop }_{i 60}+\beta_{3} a v_{-} i n s t+\varepsilon_{i} \\
& a v_{\text {_inst }}{ }_{i}=\delta_{1} c o l \_ \text {orig }+\delta_{2} \ln \text { mortal }+\omega_{i}
\end{aligned}
$$

In Table 6 we analyze the effect of the average protection against expropriation risk on the probability of civil wars using the IV-2SLS specification. The first eight columns do not include per capita income and population. In the first column we use the log of European settler mortality as an instrument for institutions. The first stage results suggest that countries where Europeans faced large settler mortality rates have lower protection against expropriation risk than countries where Europeans faced a healthier environment. Results of civil war regression indicate that the higher the protection against expropriation risk, the lower the probability of civil war. In order to obtain more observations, we include the percentage of European population or of European descendents in 1900, instead of the European settler mortality, as an alternative instrument. Results are in columns 2 and 3 . In column 2 the analysis is restricted to the sample for which we have mortality data to show that results when using European settlement in 1900 are similar to when using settler mortality data, and in column 3 we do not restrict the sample. As expected, European settlement in 1900 exhibits a positive and significant effect in explaining protection against expropriation risk.

In column 4 we include the dummies of colonial origin as an instrument for economic institutions. The first stage results indicate that countries with Napoleonic colonial origin have lower protection against expropriation risk than countries of English colonial origin. In column six, 
we include both instruments together, and find that the first stage relationship between economic institutions, colonial origin and settler mortality is strong. The F test for excluded instruments is large $(F=8.74)$, which implies that the instruments do not seem to be weak. In columns 7 and 8 we substitute the settler mortality variable with the European settlement in 1900 in order to have more observations, and qualitatively we obtain the same results. In column 7, the analysis is restricted to the sample for which we have mortality data to show that results when using European settlement in 1900 are similar to when using mortality data. In column 8 we use all observations. The first stage relationship between institutions, colonial origin and European settlement in 1900 is stronger, and the $\mathrm{F}$ test for excluded instruments is larger than when using mortality data $(\mathrm{F}=12.19)$. In all specifications, the results of civil war regression show the negative and significant effect of protection against expropriation risk on the probability of civil wars.

In columns 9 to 11 we perform the same analysis but include per capita income and population. The results of civil war regression show that protection against expropriation risk affects the probability of civil war negatively and significantly. Improving the institutional framework of a country from the value of the median to the percentile 75 , the probability of civil war is reduced by 38 percentage points. When we include the institutional variable in the regression, per capita income becomes insignificant in all specifications. As before, first stage results show that colonial origin matters in explaining institutional development. In this specification, the log of European settler mortality is not significant. However, in columns 10 and 11 we substitute the $\log$ of European settler mortality with the percentage of Europeans or European descent in 1900. In this case settlement is not significant either when we restrict the analysis to the sample for which there are mortality data (column 10). However in column 11, when 
we use all the data available, European settlement in 1900 has a significant and positive effect in explaining institutional development.

Notice that while per capita income does not have any direct effect on civil wars, it has an indirect effect through worsening institutions, when we use the reduced sample in columns 9 and 10. However, once we include European settlement in 1900 with all the data available (column 11), per capita income does not have any effect on institutions. This result is in line with the recent findings in Acemoglu et al (2006), where they test the relationship between income and democracy. They show that controlling for factors that simultaneously affect both variables removes the statistical association between income per capita and various measures of democracy.

In Table 7, we perform the same analysis as table 6 but using the law and order index from ICRG. We show the main results, which correspond to columns 6, 8, 9 and 11 of table 6 . When using the ICRG variable, the results are similar to the ones in table 5 where we use the protection against expropriation risk. The stronger the legal system, the lower the probability of civil war. Moreover, in all specifications, per capita income does not exhibit any effect on civil war. The first stage results are also in line with the results in table 6. Colonial origin and European settlement in 1900 exhibits a significant effect on the law and order variable. Once European settlement in 1900 is included as instrument, per capita income does not exhibit any indirect effect.

\subsection{Over-identification tests}

In this section we investigate the validity of our exclusion restriction condition. The Sargan test for over-identification cannot reject the null hypothesis that the instruments satisfy the orthogonality conditions $(p=0.74)$. Another issue of importance is to consider the European settlement in 1900 and colonial origin as included instruments, and therefore incorporate them into civil war 
regression and analyze whether they have any direct effect on civil wars. We approach the problem with two different strategies. In the first we add no new instrument. Therefore, to analyze the direct effect of colonial origins on civil wars, we assume that European settlement in 1900 is exogenous and therefore satisfies the orthogonality condition, and to analyze the direct effect of the European Settlement in 1900 on civil wars, we assume that colonial origin satisfies the orthogonality condition. Results are shown in columns 1 and 2, and 4 and 5 of Table 8. In columns 1 and 2 we use the protection against expropriation risk as our institutional variable, and in columns 4 and 5 we use the law and order. In columns 1 and 4 we check the validity of the colonial origin instrument, and in columns 2 and 5 the validity of the European settlement in 1900. The results indicate that colonial origin and the European settlement in 1900 have no significant direct effect on civil war.

Our second approach uses additional variables as instruments. The excluded instruments we use are a set of dummy variables that describe the quality of the soil, and are dummies for steppe (low latitude), desert (low latitude), steppe (middle latitude), desert (middle latitude), dry steppe wasteland, desert dry winter, and highland. Results are shown in columns 3 and 6 of table 8 . The results indicate that colonial origin and European settlement in 1900 have no direct effect on civil war, and they only affect conflict through its effect on institutions.

\subsection{Robustness to the use of additional instruments}

In Table 9 we test the robustness of our results to the inclusion of some additional instruments. We run four different specifications for each of the two institutional variables. From columns 1 to 4 we use protection against expropriation risk, and from columns 5 to 8 we use law and order. In the first specification, we include the absolute value of the latitude of the country. This variable measures the distance from the equator and is scaled to take values between 0 and 1 , where 0 is the equator. 
Although it is not clear why latitude should have any effect on institutions, many authors such as La Porta et al. (1999) have used it as a determinant of institutional development. In the second specification we include the time since independence, which is constructed subtracting the year of independence from 1995. The idea is that the longer the period with independence, the greater the probability that institutions will be stronger and more stable. In the third specification we include a variable that captures the health environment in 1900. We choose yellow fever. This is a dummy that equals 1 if there are yellow fever epidemics before 1900 and 0 otherwise. Finally in the fourth specification we include some variables that capture the quality of the soil. As before, in all four specifications, second stage results show the negative and significant effect of institutions on civil wars, and the lack of significance of per capita income. Moreover, first stage results indicate that colonial origin and European settlement in 1900 keep their expected significant effect and sign, while they reinforce the idea that once historical variables are controlled for, per capita income does not exhibit any indirect effect through institutions.

\subsection{Robustness to regional samples.}

In Table 10 we check the robustness of our results using different samples. From columns 1 to 2 we use the protection against expropriation risk as the institutional variable, and from columns 3 to 4 we use the law and order variable. For each of the institutional variables we run two specifications. In the first case we drop the ex-colonies that have been identified as Neo-Europes, which are Australia, Canada, United States and New Zealand. Columns 1 and 3 show that the results of the effect of institutions on civil wars are not driven by the inclusion of the Neo-Europes in the sample. In the second specification, columns 2 and 4 , we show that our results are robust to the elimination of African countries from the sample of ex-colonies. In all specifications the institutional variable 
exhibits the expected effect and sign in the civil war regression, while per capita income does not exhibit any significant effect. Moreover, first stage results show that colonial origin and European settlement in 1900 exhibit their expected effect and sign.

\section{Contracting Institutions and Civil War}

Finally we check the validity of our results using a variable that captures the efficiency of the legal system. Our purpose is to show that even the efficiency of the government in solving disputes between private agents affects conflict. The methodology of these data is described in Djankov et al (2003). Table 11 lists the ranking of countries with the lowest and the highest index of efficiency of the judicial (or administrative) system in the collection of overdue debt. The index has been standardized between 0 and 100 . Column 1 indicates the number of procedures mandated by law or court regulation that demand interaction between the parties, or between them and the judge (or administrator) or court officer, which are recorded. Twelve of the fifteen less efficient countries had a civil war during the 1960-05 period. On the other hand, only five of the fifteen countries with the most efficient legal system suffered conflict.

In table 12 we perform the basic analysis using the efficiency of the legal system as the institutional variable. In the first four columns we perform the logit analysis done in tables 4 and 5 , and from columns 4 to 8 we perform the IV analysis using the specification of table 7. In columns 1 and 2 we use the whole sample of countries, and in columns 3 and 4 we use the sample of excolonies. The index has been standardized between 0 and 1 . The results indicate that the less efficient the legal system, the higher the probability of conflict. Once we include this index together with the core variables, we find that per capita income, together with population and regulation have a significant effect on conflict. The only result which is different from the results when using 
the protection against expropriation risks and law and order, is that per capita income is significant when included together with the variable that captures contracting institutions, although this result is not robust once we take into account the reverse causality between economic institutions and civil wars (columns 5 to 8). When using the efficiency of the legal system as our institutional variable, we use the legal origin instead of the colonial origin following Djankov et al (2003) who find strong effects of legal origin on the efficiency of the legal system. Results are robust to the use of colonial origin. The first stage shows that while the legal origin is a strong instrument for contracting institutions, the log of European settler mortality is not significant when we include per capita income in the civil war regression.

\section{The endogeneity of income.}

We check whether our results are robust if we consider per capita income in 1960 as an endogenous variable (table 13). In models with two endogenous variables, instruments can be weak. Stock and Yogo (2003) provide a framework that allows testing the hypothesis of weak instruments in models with more than one endogenous variable. Although we are aware of these tests, we approach this issue in a more intuitive, although probably less rigorous, way: First of all, we identify an instrument which affects per capita income but does not affect institutions. At the same time, we need to find an instrument that explains institutions but not per capita income, which is a difficult task. Fortunately we find that while colonial origin is a strong predictor of the quality of institutions, it does not predict per capita income besides its effect on institutions. Moreover, Landlocked is a strong predictor of per capita income but not of institutions. These two instruments are practically uncorrelated. The correlation between Landlocked and Col_frsppor origin is 0.01, and the correlation between Landlocked and common law is -0.04 . 
Before considering institutions and per capita income as endogenous variables together, we first analyze the results considering only per capita income as an endogenous variable. One could think that the results in previous sections may be biased because, while we address the endogeneity problem between institutions and civil war, we do not address the endogeneity problem between per capita income and civil war. Because of this, in the first two columns we consider only per capita income as an endogenous variable. In column 1 we do not include institutions. The instruments for per capita income are Landlocked and European settlement in 1900. There is a strong relationship between Landlocked, European settlement in 1900 and per capita income. Moreover the instruments are strong. The F of excluded instruments is above the usual threshold $(F=20)$. Second stage results indicate that per capita income has a negative and significant effect on civil war, in line with the results we obtained in column 1 of table 4 . In columns 2 and 4 we include institutions as an exogenous variable, and per capita income as an endogenous variable. In column 2 we use the protection against expropriation risk, and in column 4 we use law and order. While first stage results are similar to results in column 1, second stage results are not. Once institutions are included, per capita income does not have any effect on civil wars, while institutions negatively and significantly affect civil wars. In columns 3 and 5 we consider institutions and per capita income as endogenous variables. In column 3 we use the protection against expropriation risk and in column 5 we use law and order. The instruments for institutions are colonial origin and European settlement in 1900. The instruments for per capita income are European settlement in 1900 and Landlocked. Although European settlement affects both endogenous variables, we assume that Landlocked only affects per capita income, and colonial origin only affects institutions.

First stage results indicate that while European settlement is a good predictor for per capita income and for institutions, colonial origin is a good instrument only for institutions, and 
Landlocked is a good instrument only for per capita income. The results of the civil war regression corroborate that per capita income does not affect civil war in the presence of institutions, while economic institutions have a negative and significant effect on civil wars.

\section{Conclusions}

The dominant idea in the literature on civil wars is that poverty is the main cause of conflict. In this paper we analyze the effect of institutions on civil wars. The main innovation is to consider the role of the quality of institutions in explaining civil war. We use a broad measure of the quality and efficiency of institutions as our basic variable and we address the potential endogeneity between institutions and conflict. Using a cross-section of countries and data on civil war from 1960-2005, the results of this paper indicate that the quality of institutions is an important determinant of the likelihood of conflict. Moreover, once economic institutions are considered, per capita income does not have any significant direct or indirect effect in explaining civil wars. 


\section{References}

Acemoglu, D., Johnson, S. Robinson, J.A "Reversal of Fortune: Geography and institutions in the making of the modern world income distribution" Quarterly Journal of Economics, v.117 (2002), pp.1231-1294.

"The colonial origins of comparative development: an empirical investigation” American Economic Review, v.91 (2001) pp.1369-1401.

Acemoglu, D., Johnson, S. "Unbundling Institutions”, Journal of Political Economy, v.43, 10251048 (2005)

Acemoglu, D., Johnson, S. Robinson, J.A and Pierre Yared. "Income and Democracy", (September 2006)

Alcala F, Ciccone A. (2004). “Trade and Productivity”. Quarterly Journal of Economics. May.

Angrist J.D (1991) "Instrumental Variables Estimation of Average Treatment Effects in Econometrics and Epidemiology", NBER 0115

Angrist J.D, and A. B. Krueger (2001) "Instrumental Variable and the Search for Identification: From Supply and Demand to Natural Experiments". Journal of Economic Perspectives 15:69-85

Barro, R., Determinants of economic Growth: A cross-Country Empirical study. MIT Press, Cambridge , MA. (1997)

"Economic Growth in a Cross Section of Countries," Quarterly Journal of Economics, CVI (1991) 407-43.

Botero, J., Djankov, D., La Porta, R., Lopez-de-Silanes, F., Shleifer, A., "The Regulation of Labor", Quarterly Journal of Economics, (2004), 1339-1382

Collier, P., and A. Hoeffler "Greed and Grievances in Civil Wars." Oxford Economic Papers .56, (2004)

Collier, P., Elliot, L., Hegre, H., Reynal-Querol, M., and N. Sambanis. Breaking the Conflict Trap: Civil War and Development Policy. (2003). World Bank Policy Research Report, Oxford, UK: Oxford University Press.

Djankov, Simeon, Rafael La Porta, Florencio Lopez-de-Silanes, and Andrei Shleifer, "Courts," Quarterly Journal of Economics, (2003),453-517. 
Djankov, Simeon, Rafael La Porta, Florencio Lopez-de-Silanes, and Andrei Shleifer, "The Regulation of Entry,” Quarterly Journal of Economics, (2002), 1-37.

Dollar, David and Aart Kraay, "Institutions, Trade, and Growth," Journal of Monetary Economics, 50, 1 (2003): 133-162.

Doyle, M. W., and N. Sambanis, "International Peacebuilding: A Theoretical and Quantitative Analysis." American Political Science Review, 94:4 (December 2000).

Easterly, W., and Levine, "Tropics, germs and crops: the role of endowments in economic development” Journal of Monetary Economics, 50: 1 (2003).

Fearon, J. "Primary Commodity Exports and Civil War". Journal of Conflict Resolution, vol.49, N.4 (August 2005), 483:507

Fearon, J. and Laitin, D., "Ethnicity, Insurgency, and Civil War," American Political Science Review, 97 (February 2003)

Garfinkel, M.R. (1990), “Arming as a strategic investment in a cooperative equilibrium”, American Economic Review 80: 50-68.

Glaeser, Edward, Rafael La Porta, Florencio Lopez-de-Silanes, and Andrei Shleifer, "Do Institutions Cause Growth?” Journal of Economic Growth, (2004).

Grossman, H.I (1994) “Production, appropriation, and land reform”. American Economic Review 84:705-712.

Grossman, H.I and M. Kim (1996), "Predation and Accumulation”, Journal of economic Growth 1:333-351.

Haavelmo, T. (1954), A Study in the Theory of Economic Evolution. (North-Holland, Amsterdam)

Hall, Robert, and Charles Jones, "Why Do Some Countries Produce So Much More Output per Worker than Others?” Quarterly Journal of Economics, 114,1 (1999): 83-116.

Hegre, H., Ellingsen, T., Gates, S., Gledish, N.P. Towards a democratic civil peace? Democracy, political change, and civil war, 1816-1992. American Political Science Review 95, 33-48. (2001) 
Hegre, H. and N. Sambanis. "Sensitivity Analysis of Empirical Results on Civil War Onset “. Journal of Conflict Resolution 50: 508-535. (2006)

Hirshleifer, J (1995), “Anarchy and its breakdown”, Journal of Political Economy, 103:26-52.

Knack, Stephen, and Philip Keefer, "Institutions and Economic Performance: Cross Country Testing Using Alternative Institutional Measures,” Economics and Politics, 7, 3 (1995): 207-227.

La Porta, R., Lopez de Silanes, F., Shleifer and R. Vishny, "The Quality of Government." Journal of Law, Economics and Organization, 15(1)(1999): 222-279.

Miguel, E., Satyanath, S. and E. Sergenti, "Economic Shocks and Civil Conflicts: an Instrumental Variables Approach," Journal of Political Economy, 2004.

Mauro, Paolo, “Corruption and Growth,” Quarterly Journal of Economics, 110, 3 (1995): 681-712.

Montalvo J.G, and Reynal-Querol, M., “Ethnic Polarization, Potential Conflict, and Civil Wars”, American Economic Review. 95(3), 796-816, June 2005.

Development Economic, 76 (2005) 293-323.

Persson, T., “Forms of democracy, policy and economic development,” (2004), mimeo.

Reynal-Querol, M., “Does Democracy Preempt Civil Wars?”,European Journal of Political Economy, 21 (2), June 2005, 445-465.

"Political Systems, Stability and Civil Wars”, Defense and Peace Economics, Vol. 13(6), 2002a. pp. 465-483.

"Ethnicity, Political Systems and Civil War ", Journal of Conflict Resolution. Vol. 46 N.1, February 2002b. 29-54.

Rodrick, D., “Getting Institutions Right”, (2004), mimeo

Sambanis, N. Do ethnic and non-ethnic civil wars have the same causes?: A theoretical and empirical enquiry (part 1). (2001) Journal of Conflict Resolution 45, 259-282.

Skaperdas, S (1996) “Contest Success Functions”, Economic Theory

(1992), "Cooperation, conflict, and power in the absence of property rights", American economi Review 82:720-739. 
Stock, J.H, and Yogo, M., “Testing for weak Instruments in Linear IV Regression”, Harvard University,mimeo 2003. 
Table 1: Ranking of the fifteen ex-colonies with the lowest and the highest average protection of expropriation risk

\begin{tabular}{|l|l|l|l|}
\hline Countryname & Avexpr & countryname & avexpr \\
\hline Iraq & 1.63 & United States & 10 \\
\hline Somalia & 3 & New Zealand & 9.72 \\
\hline Congo, Dem. Rep. & 3.5 & Canada & 9.72 \\
\hline Haiti & 3.72 & Singapore & 9.31 \\
\hline Sudan & 4 & Auatralia & 9.31 \\
\hline Mali & 4 & Israel & 9.54 \\
\hline Burkina Faso & 4.45 & Cyprus & 8.4 \\
\hline Uganda & 4.45 & Gambia, The & 8.27 \\
\hline Madagascar & 4.45 & India & 8.27 \\
\hline Guinea-Bissau & 4.54 & Hong Kong & 8.13 \\
\hline Congo, Rep & 4.68 & Bahrain & 8 \\
\hline El Salvador & 5 & Malaysia & 7.95 \\
\hline Níger & 5 & Brazil & 7.90 \\
\hline Guatemala & 5.13 & Chile & 7.81 \\
\hline Bangladesh & 5.13 & Gabon & 7.81 \\
\hline
\end{tabular}

Table 2: Ranking of the fifteen ex-colonies with the lowest and the highest law and order index

\begin{tabular}{|l|l|l|l|}
\hline Countryname & Laworder & countryname & ICRGlaworder \\
\hline Guinea-Bissau & 1 & Australia & 6 \\
\hline Congo, Dem.Rep & 1.06 & United States & 6 \\
\hline Colombia & 1.43 & New Zealand & 6 \\
\hline Iraq & 1.62 & Canada & 6 \\
\hline Haiti & 1.62 & Singapore & 5.37 \\
\hline Bolivia & 1.81 & Hong Kong & 4.93 \\
\hline Guatemala & 1.81 & Namibia & 4.8 \\
\hline Sri Lanka & 1.81 & Botswana & 4.73 \\
\hline Angola & 1.87 & Bahrain & 4.62 \\
\hline El Salvador & 1.87 & Saudi Arabia & 4.43 \\
\hline Bangladesh & 1.87 & Chile & 4.37 \\
\hline Peru & 1.87 & Qatar & 4.26 \\
\hline Sudan & 2. & Malta & 4.21 \\
\hline Somalia & 2 & Malaysia & \\
\hline Nigeria & 2.06 & Oman & 4.18 \\
\hline
\end{tabular}


Table 3: Logit analysis on the causes of civil wars. Sample of all-countries.

\begin{tabular}{llllll}
\hline & PRIOCW & PRIOCW & PRIOCW & PRIOCW & PRIOCW \\
\hline & $(1)$ & $(2)$ & $(3)$ & $(4)$ & $(5)$ \\
\hline Lngdp60 & -1.13 & & 0.29 & & 0.32 \\
& $(-4.05)$ & & $(0.71)$ & & $(0.81)$ \\
Lpop60 & 0.33 & & 0.37 & & 0.33 \\
& $(2.17)$ & & $(1.89)$ & & $(1.60)$ \\
Avexpr & & -0.99 & -1.28 & & \\
& & $(-5.66)$ & $(-4.71)$ & & \\
ICRGlaword & & & & -1.24 & -1.67 \\
& & & & $(-6.28)$ & $(-5.12)$ \\
Constant & 3.63 & 7.62 & 2.06 & 4.75 & -0.79 \\
& $(1.46)$ & $(5.71)$ & $(0.53)$ & $(6.14)$ & $(-0.19)$ \\
N & & & & & \\
R-squared & 128 & 121 & 110 & 140 & 110 \\
\hline
\end{tabular}

Note: z-statistics in parentheses. 
Table 4 : Robust analysis of the logit regressions. Sample of all countries

\begin{tabular}{|c|c|c|c|c|c|c|c|c|c|c|}
\hline & $\begin{array}{l}\text { PRIOCW } \\
(1) \\
\end{array}$ & $\begin{array}{l}\text { PRIOCW } \\
(2) \\
\end{array}$ & $\begin{array}{l}\text { PRIOCW } \\
\text { (3) }\end{array}$ & $\begin{array}{l}\text { PRIOCW } \\
(4)\end{array}$ & $\begin{array}{l}\text { PRIOCW } \\
\text { (5) }\end{array}$ & $\begin{array}{l}\text { PRIOCW } \\
\text { (6) }\end{array}$ & $\begin{array}{l}\text { PRIOCW } \\
(7) \\
\end{array}$ & $\begin{array}{l}\text { PRIOCW } \\
(8) \\
\end{array}$ & $\begin{array}{l}\text { PRIOCW } \\
\text { (9) }\end{array}$ & $\begin{array}{l}\text { PRIOCW } \\
(10)\end{array}$ \\
\hline Avexpr & & & & & & $\begin{array}{l}-1.29 \\
(-4.06)\end{array}$ & $\begin{array}{l}-1.31 \\
(-4.05)\end{array}$ & $\begin{array}{l}-1.40 \\
(-3.99)\end{array}$ & $\begin{array}{l}-1.30 \\
(-3.95)\end{array}$ & $\begin{array}{l}-1.41 \\
(-4.49)\end{array}$ \\
\hline Lngdp60 & $\begin{array}{l}-1.31 \\
(-4.10)\end{array}$ & $\begin{array}{l}-1.26 \\
(-3.93)\end{array}$ & $\begin{array}{l}-1.22 \\
(-3.69)\end{array}$ & $\begin{array}{l}-1.14 \\
(-3.44)\end{array}$ & $\begin{array}{l}-1.12 \\
(-2.59)\end{array}$ & $\begin{array}{l}0.11 \\
(0.20)\end{array}$ & $\begin{array}{l}0.18 \\
(0.33)\end{array}$ & $\begin{array}{l}0.13 \\
(0.25)\end{array}$ & $\begin{array}{l}0.13 \\
(0.25)\end{array}$ & $\begin{array}{l}0.09 \\
(0.14)\end{array}$ \\
\hline Lpop60 & $\begin{array}{l}0.37 \\
(2.30)\end{array}$ & $\begin{array}{l}0.31 \\
(1.73)\end{array}$ & $\begin{array}{l}0.35 \\
(1.78)\end{array}$ & $\begin{array}{l}0.43 \\
(2.02)\end{array}$ & $\begin{array}{l}0.27 \\
(0.96)\end{array}$ & $\begin{array}{l}0.50 \\
(1.93)\end{array}$ & $\begin{array}{l}0.55 \\
(1.91)\end{array}$ & $\begin{array}{l}0.46 \\
(1.56)\end{array}$ & $\begin{array}{l}0.55 \\
(1.70)\end{array}$ & $\begin{array}{l}0.47 \\
(1.16)\end{array}$ \\
\hline Goldm & $\begin{array}{l}0.11 \\
(2.57)\end{array}$ & $\begin{array}{l}0.10 \\
(2.52)\end{array}$ & $\begin{array}{l}0.10 \\
(2.42)\end{array}$ & $\begin{array}{l}0.10 \\
(2.22)\end{array}$ & $\begin{array}{l}0.08 \\
(2.04)\end{array}$ & $\begin{array}{l}0.07 \\
(1.87)\end{array}$ & $\begin{array}{l}0.07 \\
(1.75)\end{array}$ & $\begin{array}{l}0.07 \\
(1.83)\end{array}$ & $\begin{array}{l}0.06 \\
(1.61)\end{array}$ & $\begin{array}{l}0.05 \\
(1.19)\end{array}$ \\
\hline Silv & $\begin{array}{l}0.15 \\
(0.76)\end{array}$ & $\begin{array}{l}0.13 \\
(0.67)\end{array}$ & $\begin{array}{l}0.11 \\
(0.55)\end{array}$ & $\begin{array}{l}0.01 \\
(0.05)\end{array}$ & $\begin{array}{l}-0.01 \\
(-0.08)\end{array}$ & $\begin{array}{l}-0.16 \\
(-0.88)\end{array}$ & $\begin{array}{l}-0.14 \\
(-0.74)\end{array}$ & $\begin{array}{l}-0.09 \\
(-0.50)\end{array}$ & $\begin{array}{l}-0.13 \\
(-0.74)\end{array}$ & $\begin{array}{l}-0.14 \\
(-0.71)\end{array}$ \\
\hline Zinc & $\begin{array}{l}0.01 \\
(0.02)\end{array}$ & $\begin{array}{l}0.01 \\
(0.04)\end{array}$ & $\begin{array}{l}0.04 \\
(0.13)\end{array}$ & $\begin{array}{l}0.14 \\
(0.46)\end{array}$ & $\begin{array}{l}0.17 \\
(0.64)\end{array}$ & $\begin{array}{l}0.41 \\
(1.25)\end{array}$ & $\begin{array}{l}0.37 \\
(1.12)\end{array}$ & $\begin{array}{l}0.30 \\
(0.90)\end{array}$ & $\begin{array}{l}0.30 \\
(0.94)\end{array}$ & $\begin{array}{l}0.32 \\
(1.03)\end{array}$ \\
\hline Oilres & $\begin{array}{l}0.000 \\
(1.65)\end{array}$ & $\begin{array}{l}0.00 \\
(1.58)\end{array}$ & $\begin{array}{l}0.00 \\
(1.53)\end{array}$ & $\begin{array}{l}0.00 \\
(1.97)\end{array}$ & $\begin{array}{l}0.00 \\
(2.10)\end{array}$ & $\begin{array}{l}0.00 \\
(1.95)\end{array}$ & $\begin{array}{l}0.00 \\
(2.03)\end{array}$ & $\begin{array}{l}0.00 \\
(2.13)\end{array}$ & $\begin{array}{l}0.00 \\
(2.50)\end{array}$ & $\begin{array}{l}0.00 \\
(2.49)\end{array}$ \\
\hline Mount & & $\begin{array}{l}0.01 \\
(0.54)\end{array}$ & $\begin{array}{l}0.01 \\
(0.47)\end{array}$ & $\begin{array}{l}0.002 \\
(0.29)\end{array}$ & $\begin{array}{l}-0.004 \\
(-0.34)\end{array}$ & & $\begin{array}{l}-0.012 \\
(-0.65)\end{array}$ & $\begin{array}{l}-0.01 \\
(-0.57)\end{array}$ & $\begin{array}{l}-0.02 \\
(-0.75)\end{array}$ & $\begin{array}{l}-0.03 \\
(-1.08)\end{array}$ \\
\hline Ncontig & & & $\begin{array}{l}-0.36 \\
(-0.54)\end{array}$ & $\begin{array}{l}0.01 \\
(0.02)\end{array}$ & $\begin{array}{l}-0.04 \\
(-0.05)\end{array}$ & & & $\begin{array}{l}0.92 \\
(1.13)\end{array}$ & $\begin{array}{l}1.3 \\
(1.48)\end{array}$ & $\begin{array}{l}1.00 \\
(0.89)\end{array}$ \\
\hline ETHPOL & & & & $\begin{array}{l}2.85 \\
(2.79)\end{array}$ & $\begin{array}{l}3.38 \\
(2.81)\end{array}$ & & & & $\begin{array}{l}2.75 \\
(2.09)\end{array}$ & $\begin{array}{l}3.22 \\
(2.12)\end{array}$ \\
\hline Democ1965 & & & & & $\begin{array}{l}0.01 \\
(0.13)\end{array}$ & & & & & $\begin{array}{l}0.06 \\
(0.52)\end{array}$ \\
\hline Constant & $\begin{array}{l}4.39 \\
(1.35)\end{array}$ & $\begin{array}{l}4.85 \\
(1.41)\end{array}$ & $\begin{array}{l}4.04 \\
(1.05)\end{array}$ & $\begin{array}{l}0.48 \\
(0.12)\end{array}$ & $\begin{array}{l}2.77 \\
(0.48)\end{array}$ & $\begin{array}{l}1.26 \\
(0.22)\end{array}$ & $\begin{array}{l}0.28 \\
(0.05)\end{array}$ & $\begin{array}{l}2.49 \\
(0.42)\end{array}$ & $\begin{array}{l}-1.07 \\
(-0.17)\end{array}$ & $\begin{array}{l}1.01 \\
(0.13)\end{array}$ \\
\hline $\mathrm{N}$ & 120 & 115 & 115 & 114 & 96 & 106 & 104 & 104 & 103 & 90 \\
\hline R-squared & 0.2336 & 0.2163 & 0.2181 & 0.2679 & 0.2819 & 0.4297 & 0.4293 & 0.4373 & 0.4651 & 0.4894 \\
\hline
\end{tabular}

Note: z-statistics in parentheses.

Table 5: Logit analysis on the causes of civil war using the sample of Ex-colonies

\begin{tabular}{llllll}
\hline & PRIOCW & PRIOCW & PRIOCW & PRIOCW & PRIOCW \\
\hline Lngdp60 & $(1)$ & $(2)$ & $(3)$ & $(4)$ & $(5)$ \\
& -0.92 & & 0.09 & & 0.13 \\
Lpop60 & $(-2.28)$ & & $(0.20)$ & & $(0.32)$ \\
& 0.66 & & 0.42 & & 0.43 \\
Avexpr & $(2.89)$ & & $(2.22)$ & & $(1.91)$ \\
ICRGlaword & & -0.88 & -1.00 & & \\
& & $(-4.20)$ & $(-3.19)$ & & -1.30 \\
Constant & & & & -1.35 & $(-3.71)$ \\
& -2.49 & 6.88 & & $(-4.66)$ & -2.14 \\
N & $(-0.60)$ & $(4.54)$ & $(0.21)$ & $(4.94)$ & $(-0.49)$ \\
R-squared & 95 & 87 & 80 & & 81 \\
\hline
\end{tabular}

Note: z-statistics in parentheses. 
Table 6: IV-2SLS regressions on institutions and Civil wars.

\begin{tabular}{|c|c|c|c|c|c|c|c|c|c|c|c|}
\hline & PRIOCW & PRIOCW & PRIOCW & PRIOCW & PRIOCW & PRIOCW & PRIOCW & PRIOCW & PRIOCW & PRIOCW & PRIOCW \\
\hline & (1) & (2) & (3) & (4) & (5) & (6) & (7) & (8) & (9) & (10) & (11) \\
\hline Avexpr & $\begin{array}{l}-0.27 \\
(-4.24)\end{array}$ & $\begin{array}{l}-0.22 \\
(-5.95)\end{array}$ & $\begin{array}{l}-0.20 \\
(-4.44)\end{array}$ & $\begin{array}{l}-0.35 \\
(-2.44)\end{array}$ & $\begin{array}{l}-0.28 \\
(-2.58)\end{array}$ & $\begin{array}{l}-0.26 \\
(-4.42)\end{array}$ & $\begin{array}{l}-0.22 \\
(-7.86)\end{array}$ & $\begin{array}{l}-0.24 \\
(-7.37)\end{array}$ & $\begin{array}{l}-0.36 \\
(-2.98)\end{array}$ & $\begin{array}{l}-0.33 \\
(-2.58)\end{array}$ & $\begin{array}{l}-0.38 \\
(-4.35)\end{array}$ \\
\hline Lngdp60 & & & & & & & & & $\begin{array}{l}0.17 \\
(1.23)\end{array}$ & $\begin{array}{l}0.14 \\
(0.87)\end{array}$ & $\begin{array}{l}0.20 \\
(1.58)\end{array}$ \\
\hline Lpop60 & & & & & & & & & $\begin{array}{l}0.09 \\
(1.81)\end{array}$ & $\begin{array}{l}0.08 \\
(1.42)\end{array}$ & $\begin{array}{l}0.07 \\
(1.71)\end{array}$ \\
\hline Constant & $\begin{array}{l}2.50 \\
(6.11)\end{array}$ & $\begin{array}{l}2.23 \\
(8.68)\end{array}$ & $\begin{array}{l}1.97 \\
(6.59)\end{array}$ & $\begin{array}{l}2.96 \\
(3.22)\end{array}$ & $\begin{array}{l}2.52 \\
(3.58)\end{array}$ & $\begin{array}{l}2.44 \\
(6.43)\end{array}$ & $\begin{array}{l}2.24 \\
(11.25)\end{array}$ & $\begin{array}{l}2.28 \\
(10.17)\end{array}$ & $\begin{array}{l}0.51 \\
(0.52)\end{array}$ & $\begin{array}{l}0.72 \\
(0.64)\end{array}$ & $\begin{array}{l}0.59 \\
(0.66)\end{array}$ \\
\hline $\mathrm{N}$ & 67 & & 86 & 87 & 87 & 67 & & 86 & 66 & 65 & 79 \\
\hline First Stage & Avexpr & $\begin{array}{l}\text { Sample of } \\
\text { mortality } \\
\text { Avexpr }\end{array}$ & Avexpr & Avexpr & Avexpr & Avexpr & $\begin{array}{l}\text { Sample of } \\
\text { mortality } \\
\text { Avexpr }\end{array}$ & Avexpr & Avexpr & $\begin{array}{l}\text { Sample of } \\
\text { mortality } \\
\text { Avexpr }\end{array}$ & Avexpr \\
\hline Lngdp60 & & & & & & & & & $\begin{array}{l}0.94 \\
(4.35)\end{array}$ & $\begin{array}{l}0.79 \\
(2.69)\end{array}$ & $\begin{array}{l}0.38 \\
(1.44)\end{array}$ \\
\hline Lpop60 & & & & & & & & & $\begin{array}{l}0.06 \\
(0.65)\end{array}$ & $\begin{array}{l}0.06 \\
(0.59)\end{array}$ & $\begin{array}{l}-0.02 \\
(-0.25)\end{array}$ \\
\hline Col_frspport & & & & $\begin{array}{l}-0.79 \\
(-2.42)\end{array}$ & & $\begin{array}{l}-0.62 \\
(-1.82)\end{array}$ & $\begin{array}{l}-0.96 \\
(-3.17)\end{array}$ & $\begin{array}{l}-0.91 \\
(-3.18)\end{array}$ & $\begin{array}{l}-0.72 \\
(-2.35)\end{array}$ & $\begin{array}{l}-0.84 \\
(-2.78)\end{array}$ & $\begin{array}{l}-0.79 \\
(-2.54)\end{array}$ \\
\hline Col_other & & & & $\begin{array}{l}-1.05 \\
(-1.65)\end{array}$ & & $\begin{array}{l}-0.68 \\
(-1.10)\end{array}$ & $\begin{array}{l}-0.62 \\
(-1.07)\end{array}$ & $\begin{array}{l}-0.73 \\
(-1.30)\end{array}$ & $\begin{array}{l}0.13 \\
(0.22)\end{array}$ & $\begin{array}{l}0.01 \\
(0.01)\end{array}$ & $\begin{array}{l}-0.09 \\
(-0.14)\end{array}$ \\
\hline Legor_fr & & & & & $\begin{array}{l}-0.94 \\
(-3.02)\end{array}$ & & & & & & \\
\hline LnACmortality & $\begin{array}{l}-0.59 \\
(-4.70)\end{array}$ & & & & & $\begin{array}{l}-0.51 \\
(-3.89)\end{array}$ & & & $\begin{array}{l}-0.16 \\
(-1.13)\end{array}$ & & \\
\hline Euro1900 & & $\begin{array}{l}0.031 \\
(5.19)\end{array}$ & $\begin{array}{l}0.03 \\
(4.88)\end{array}$ & & & & $\begin{array}{l}0.03 \\
(5.29)\end{array}$ & $\begin{array}{l}0.03 \\
(5.26)\end{array}$ & & $\begin{array}{l}0.01 \\
(1.20)\end{array}$ & $\begin{array}{l}0.02 \\
(2.90)\end{array}$ \\
\hline Constant & $\begin{array}{l}9.25 \\
(15.21)\end{array}$ & $\begin{array}{l}5.98 \\
(33.29)\end{array}$ & $\begin{array}{l}6.09 \\
(37.02)\end{array}$ & $\begin{array}{l}6.92 \\
(30.22)\end{array}$ & $\begin{array}{l}7.01 \\
(29.98)\end{array}$ & $\begin{array}{l}9.24 \\
(15.39)\end{array}$ & $\begin{array}{l}6.55 \\
(26.03)\end{array}$ & $\begin{array}{l}6.55 \\
(30.67)\end{array}$ & $\begin{array}{l}-0.08 \\
(-0.03)\end{array}$ & $\begin{array}{l}0.10 \\
(0.04)\end{array}$ & $\begin{array}{l}4.13 \\
(1.60)\end{array}$ \\
\hline R-squared & 0.2538 & 0.2962 & 0.2209 & 0.0770 & 0.0967 & $0.2940)$ & 0.3947 & 0.3084 & 0.4639 & 0.4653 & 0.3379 \\
\hline
\end{tabular}

Note: t-statistics in parentheses. 
Table 7. IV-2SLS regressions on institutions and Civil wars using data on law and order.

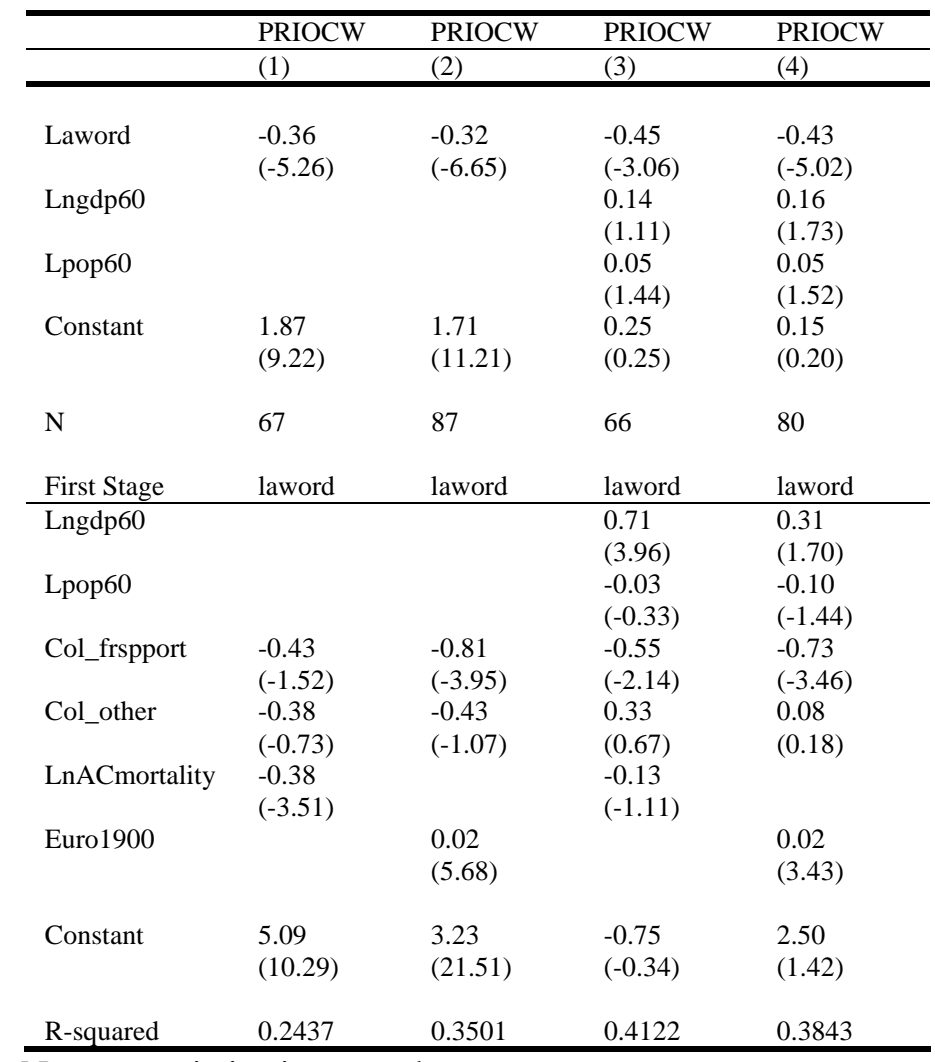

Note: t-statistics in parentheses. 
Table 8. IV-2SLS. Overidentification analysis

\begin{tabular}{|c|c|c|c|c|c|c|}
\hline & $\begin{array}{l}\text { PRIOCW } \\
\text { (1) }\end{array}$ & $\begin{array}{l}\text { PRIOCW } \\
\text { (2) }\end{array}$ & $\begin{array}{l}\text { PRIOCW } \\
\text { (3) }\end{array}$ & $\begin{array}{l}\text { PRIOCW } \\
\text { (4) }\end{array}$ & $\begin{array}{l}\text { PRIOCW } \\
\text { (5) }\end{array}$ & $\begin{array}{l}\text { PRIOCW } \\
(6)\end{array}$ \\
\hline Avexpr & $\begin{array}{l}-0.37 \\
(-2.73)\end{array}$ & $\begin{array}{l}-0.40 \\
(-2.57)\end{array}$ & $\begin{array}{l}-0.27 \\
(-2.51)\end{array}$ & & & \\
\hline Laword & & & & $\begin{array}{l}-0.44 \\
(-3.49)\end{array}$ & $\begin{array}{l}-0.44 \\
(-3.17)\end{array}$ & $\begin{array}{l}-0.031 \\
(-2.29)\end{array}$ \\
\hline Lngdp60 & $\begin{array}{l}0.19 \\
(1.08)\end{array}$ & $\begin{array}{l}0.20 \\
(1.53)\end{array}$ & $\begin{array}{l}0.23 \\
(1.89)\end{array}$ & $\begin{array}{l}0.17 \\
(1.37)\end{array}$ & $\begin{array}{l}0.16 \\
(1.70)\end{array}$ & $\begin{array}{l}0.13 \\
(1.44)\end{array}$ \\
\hline Lpop60 & $\begin{array}{l}0.07 \\
(1.73)\end{array}$ & $\begin{array}{l}0.07 \\
(1.62)\end{array}$ & $\begin{array}{l}0.08 \\
(1.79)\end{array}$ & $\begin{array}{l}0.05 \\
(1.29)\end{array}$ & $\begin{array}{l}0.05 \\
(1.61)\end{array}$ & $\begin{array}{l}0.06 \\
(1.62)\end{array}$ \\
\hline Col_frspport & $\begin{array}{l}0.02 \\
(0.15)\end{array}$ & & $\begin{array}{l}0.08 \\
(0.57)\end{array}$ & $\begin{array}{l}0.006 \\
(0.04)\end{array}$ & & $\begin{array}{l}0.10 \\
(0.74)\end{array}$ \\
\hline Col_other & $\begin{array}{l}0.00 \\
(0.01)\end{array}$ & & $\begin{array}{l}0.05 \\
(0.25)\end{array}$ & $\begin{array}{l}0.07 \\
(0.37)\end{array}$ & & $\begin{array}{l}0.06 \\
(0.36)\end{array}$ \\
\hline Euro1900 & & $\begin{array}{l}0.00 \\
(0.14)\end{array}$ & $\begin{array}{l}-0.00 \\
(-1.16)\end{array}$ & & $\begin{array}{l}0.00 \\
(0.01)\end{array}$ & $\begin{array}{l}-0.00 \\
(-0.83)\end{array}$ \\
\hline Constant & $\begin{array}{l}0.57 \\
(0.65)\end{array}$ & $\begin{array}{l}0.71 \\
(0.52)\end{array}$ & $\begin{array}{l}-0.41 \\
(-0.37)\end{array}$ & $\begin{array}{l}0.12 \\
(0.15)\end{array}$ & $\begin{array}{l}0.15 \\
(0.19)\end{array}$ & $\begin{array}{l}-0.22 \\
(-0.25)\end{array}$ \\
\hline $\begin{array}{l}\mathrm{N} \\
\text { First Stage }\end{array}$ & $\begin{array}{l}79 \\
\text { Avexpr }\end{array}$ & $\begin{array}{l}79 \\
\text { Avexpr }\end{array}$ & $\begin{array}{l}79 \\
\text { avexpr }\end{array}$ & $\begin{array}{l}80 \\
\text { Laword }\end{array}$ & $\begin{array}{l}80 \\
\text { laword }\end{array}$ & $\begin{array}{l}80 \\
\text { Laword }\end{array}$ \\
\hline Lngdp60 & $\begin{array}{l}0.38 \\
(1.44)\end{array}$ & $\begin{array}{l}0.38 \\
(1.44)\end{array}$ & $\begin{array}{l}0.63 \\
(1.78)\end{array}$ & $\begin{array}{l}0.31 \\
(1.70)\end{array}$ & $\begin{array}{l}0.31 \\
(1.70)\end{array}$ & $\begin{array}{l}0.28 \\
(1.43)\end{array}$ \\
\hline Lpop60 & $\begin{array}{l}-0.03 \\
(-0.25)\end{array}$ & $\begin{array}{l}-0.03 \\
(-0.25)\end{array}$ & $\begin{array}{l}0.08 \\
(0.65)\end{array}$ & $\begin{array}{l}-0.10 \\
(-1.44)\end{array}$ & $\begin{array}{l}-0.10 \\
(-1.44)\end{array}$ & $\begin{array}{l}-0.12 \\
(-1.63)\end{array}$ \\
\hline Col_frspport & $\begin{array}{l}-0.79 \\
(-2.54)\end{array}$ & $\begin{array}{l}-0.79 \\
(-2.54)\end{array}$ & $\begin{array}{l}-0.69 \\
(-1.90)\end{array}$ & $\begin{array}{l}-0.73 \\
(-3.46)\end{array}$ & $\begin{array}{l}-0.73 \\
(-3.46)\end{array}$ & $\begin{array}{l}-0.74 \\
(-3.42)\end{array}$ \\
\hline Col_other & $\begin{array}{l}-0.09 \\
(-0.14)\end{array}$ & $\begin{array}{l}-0.09 \\
(-0.14)\end{array}$ & $\begin{array}{l}-0.20 \\
(-0.29)\end{array}$ & $\begin{array}{l}0.08 \\
(0.18)\end{array}$ & $\begin{array}{l}0.08 \\
(0.18)\end{array}$ & $\begin{array}{l}0.18 \\
(0.37)\end{array}$ \\
\hline $\begin{array}{l}\text { Euro1900 } \\
\text { Geography }\end{array}$ & $\begin{array}{l}0.02 \\
(2.90)\end{array}$ & $\begin{array}{l}0.02 \\
(2.90)\end{array}$ & $\begin{array}{l}0.02 \\
(1.46) \\
\text { Included }\end{array}$ & $\begin{array}{l}0.02 \\
(3.43)\end{array}$ & $\begin{array}{l}0.02 \\
(3.43)\end{array}$ & $\begin{array}{l}0.02 \\
\text { (3.08) } \\
\text { Included }\end{array}$ \\
\hline Constant & $\begin{array}{l}4.13 \\
(1.60)\end{array}$ & $\begin{array}{l}4.13 \\
(1.60)\end{array}$ & $\begin{array}{l}1.01 \\
(0.33)\end{array}$ & $\begin{array}{l}2.50 \\
(1.42)\end{array}$ & $\begin{array}{l}2.50 \\
(1.42)\end{array}$ & $\begin{array}{l}2.92 \\
(1.56)\end{array}$ \\
\hline R-squared & 0.3379 & 0.3379 & 0.4546 & 0.4233 & 0.4233 & 0.4694 \\
\hline
\end{tabular}

Note: t-statistics in parentheses. 


\section{Table 9. Robustness checks for IV-2SLS Regressions to the use of additional instruments.}

\begin{tabular}{|c|c|c|c|c|c|c|c|c|}
\hline & PRIOCW & PRIOCW & PRIOCW & PRIOCW & PRIOCW & PRIOCW & PRIOCW & PRIOCW \\
\hline $\begin{array}{l}\text { Institutional } \\
\text { variable used }\end{array}$ & Avexpr & Avexpr & Avexpr & Avexpr & ICRGlaword & ICRGlaword & ICRGlaword & ICRGlaword \\
\hline & (1) & (2) & (3) & (4) & (5) & (6) & (7) & (8) \\
\hline $\begin{array}{l}\text { Institutional } \\
\text { variable }\end{array}$ & $\begin{array}{l}-0.38 \\
(-4.32)\end{array}$ & $\begin{array}{l}-0.41 \\
(-3.52)\end{array}$ & $\begin{array}{l}-0.34 \\
(-4.42)\end{array}$ & $\begin{array}{l}-0.35 \\
(-4.71)\end{array}$ & $\begin{array}{l}-0.38 \\
(-5.04)\end{array}$ & $\begin{array}{l}-0.38 \\
(-4.92)\end{array}$ & $\begin{array}{l}-0.38 \\
(-4.82)\end{array}$ & $\begin{array}{l}-0.40 \\
(-5.92)\end{array}$ \\
\hline Lngdp60 & $\begin{array}{l}0.20 \\
(1.58)\end{array}$ & $\begin{array}{l}0.26 \\
(1.85)\end{array}$ & $\begin{array}{l}0.16 \\
(1.48)\end{array}$ & $\begin{array}{l}0.17 \\
(1.58)\end{array}$ & $\begin{array}{l}0.12 \\
(1.45)\end{array}$ & $\begin{array}{l}0.14 \\
(1.51)\end{array}$ & $\begin{array}{l}0.12 \\
(1.40)\end{array}$ & $\begin{array}{l}0.14 \\
(1.74)\end{array}$ \\
\hline Lpop60 & $\begin{array}{l}0.07 \\
(1.71)\end{array}$ & $\begin{array}{l}0.08 \\
(1.44)\end{array}$ & $\begin{array}{l}0.07 \\
(1.79)\end{array}$ & $\begin{array}{l}0.07 \\
(1.78)\end{array}$ & $\begin{array}{l}0.05 \\
(1.65)\end{array}$ & $\begin{array}{l}0.04 \\
(1.34)\end{array}$ & $\begin{array}{l}0.05 \\
1.67)\end{array}$ & $\begin{array}{l}0.05 \\
(1.57)\end{array}$ \\
\hline Constant & $\begin{array}{l}0.59 \\
(0.66)\end{array}$ & $\begin{array}{l}0.23 \\
(0.21)\end{array}$ & $\begin{array}{l}0.62 \\
(0.76)\end{array}$ & $\begin{array}{l}0.62 \\
(0.74)\end{array}$ & $\begin{array}{l}0.22 \\
(0.31)\end{array}$ & $\begin{array}{l}0.23 \\
(0.30)\end{array}$ & $\begin{array}{l}0.23 \\
(0.33)\end{array}$ & $\begin{array}{l}0.19 \\
(0.27)\end{array}$ \\
\hline $\mathrm{N}$ & 79 & 69 & 79 & 79 & 80 & 70 & 80 & 80 \\
\hline First Stage & Avexpr & Avexpr & Avexpr & Avexpr & ICRGlaword & ICRGlaword & ICRGlaword & ICRGlaword \\
\hline Lngdp60 & $\begin{array}{l}0.39 \\
(1.42)\end{array}$ & $\begin{array}{l}0.60 \\
(1.79)\end{array}$ & $\begin{array}{l}0.32 \\
(1.14)\end{array}$ & $\begin{array}{l}0.32 \\
(1.10)\end{array}$ & $\begin{array}{l}0.24 \\
(1.30)\end{array}$ & $\begin{array}{l}0.21 \\
(0.88)\end{array}$ & $\begin{array}{l}0.24 \\
(1.30)\end{array}$ & $\begin{array}{l}0.28 \\
(1.43)\end{array}$ \\
\hline Lpop60 & $\begin{array}{l}-0.02 \\
(-0.21)\end{array}$ & $\begin{array}{l}0.02 \\
(0.22)\end{array}$ & $\begin{array}{l}-0.04 \\
(-0.40)\end{array}$ & $\begin{array}{l}0.03 \\
(0.25)\end{array}$ & $\begin{array}{l}-0.13 \\
(-1.81)\end{array}$ & $\begin{array}{l}-0.09 \\
(-1.11)\end{array}$ & $\begin{array}{l}-0.12 \\
(-1.66)\end{array}$ & $\begin{array}{l}-0.12 \\
(-1.63)\end{array}$ \\
\hline Col_frspport & $\begin{array}{l}-0.79 \\
(-2.51)\end{array}$ & $\begin{array}{l}-0.79 \\
(-2.24)\end{array}$ & $\begin{array}{l}-0.78 \\
(-2.53)\end{array}$ & $\begin{array}{l}-0.78 \\
(-2.42)\end{array}$ & $\begin{array}{l}-0.67 \\
(-3.21)\end{array}$ & $\begin{array}{l}-0.63 \\
(-2.44)\end{array}$ & $\begin{array}{l}-0.73 \\
(-3.49)\end{array}$ & $\begin{array}{l}-0.74 \\
(-3.42)\end{array}$ \\
\hline Col_other & $\begin{array}{l}-0.11 \\
(-0.16)\end{array}$ & $\begin{array}{l}-0.04 \\
(-0.07)\end{array}$ & $\begin{array}{l}-0.04 \\
(-0.06)\end{array}$ & $\begin{array}{l}-0.44 \\
(-0.58)\end{array}$ & $\begin{array}{l}0.27 \\
(0.57)\end{array}$ & $\begin{array}{l}0.06 \\
(0.13)\end{array}$ & $\begin{array}{l}0.14 \\
(0.29)\end{array}$ & $\begin{array}{l}0.18 \\
(0.37)\end{array}$ \\
\hline Euro1900 & $\begin{array}{l}0.02 \\
(2.87)\end{array}$ & $\begin{array}{l}0.02 \\
(1.58)\end{array}$ & $\begin{array}{l}0.02 \\
(2.96)\end{array}$ & $\begin{array}{l}0.02 \\
(2.71)\end{array}$ & $\begin{array}{l}0.02 \\
(3.20)\end{array}$ & $\begin{array}{l}0.02 \\
(3.15)\end{array}$ & $\begin{array}{l}0.02 \\
(3.54)\end{array}$ & $\begin{array}{l}0.02 \\
(3.08)\end{array}$ \\
\hline Latitude & $\begin{array}{l}-0.16 \\
(-0.11)\end{array}$ & & & & $\begin{array}{l}1.55 \\
(1.65)\end{array}$ & & & \\
\hline Ind. time & & $\begin{array}{l}-0.00 \\
(-0.10)\end{array}$ & & & & $\begin{array}{l}-0.00 \\
(-0.55)\end{array}$ & & \\
\hline Yellow & & & $\begin{array}{l}-0.32 \\
(-0.92)\end{array}$ & & & & $\begin{array}{l}-0.32 \\
(-1.34)\end{array}$ & \\
\hline Soil & & & & included & & & & Included \\
\hline Constant & $\begin{array}{l}4.06 \\
(1.52)\end{array}$ & $\begin{array}{l}1.94 \\
(0.66)\end{array}$ & $\begin{array}{l}5.10 \\
(1.83)\end{array}$ & $\begin{array}{l}3.94 \\
(1.40)\end{array}$ & $\begin{array}{l}3.13 \\
(1.76)\end{array}$ & $\begin{array}{l}2.98 \\
(1.38)\end{array}$ & $\begin{array}{l}3.46 \\
(1.83)\end{array}$ & \\
\hline R-sqaured & 0.3380 & 0.3958 & 0.3456 & 0.3691 & 0.4440 & 0.4520 & 0.4371 & 0.4694 \\
\hline
\end{tabular}

Note: t-statistics in parentheses. 
Table 10. Robustness checks for IV-2SLS

Regressions to regional samples

\begin{tabular}{|c|c|c|c|c|}
\hline & PRIOCW & PRIOCW & PRIOCW & PRIOCW \\
\hline $\begin{array}{l}\text { Institutional } \\
\text { variable used }\end{array}$ & Avexpr & Avexpr & ICRGlaword & ICRGlaword \\
\hline \multirow[t]{2}{*}{ Sample } & $\begin{array}{l}\text { Without } \\
\text { Neo- } \\
\text { Europes }\end{array}$ & $\begin{array}{l}\text { without } \\
\text { African } \\
\text { countries }\end{array}$ & $\begin{array}{l}\text { Without } \\
\text { Neo- } \\
\text { Europes }\end{array}$ & $\begin{array}{l}\text { without } \\
\text { African } \\
\text { countries }\end{array}$ \\
\hline & (1) & $(2)$ & (3) & (4) \\
\hline $\begin{array}{l}\text { Institutional } \\
\text { variable }\end{array}$ & $\begin{array}{l}-0.40 \\
(-2.69)\end{array}$ & $\begin{array}{l}-2.55 \\
(-4.13)\end{array}$ & $\begin{array}{l}-0.56 \\
(-2.48)\end{array}$ & $\begin{array}{l}-0.34 \\
(-3.97)\end{array}$ \\
\hline Lngdp60 & $\begin{array}{l}0.21 \\
(1.57)\end{array}$ & $\begin{array}{l}0.07 \\
(0.66)\end{array}$ & $\begin{array}{l}0.17 \\
(1.45)\end{array}$ & $\begin{array}{l}0.17 \\
(1.24)\end{array}$ \\
\hline Lpop60 & $\begin{array}{l}0.08 \\
(1.49)\end{array}$ & $\begin{array}{l}0.10 \\
(2.38)\end{array}$ & $\begin{array}{l}0.03 \\
(0.63)\end{array}$ & $\begin{array}{l}0.07 \\
(1.66)\end{array}$ \\
\hline Constant & $\begin{array}{l}0.65 \\
(0.51)\end{array}$ & $\begin{array}{l}0.35 \\
(0.34)\end{array}$ & $\begin{array}{l}0.81 \\
(0.72)\end{array}$ & $\begin{array}{l}-0.57 \\
(-0.44)\end{array}$ \\
\hline $\mathrm{N}$ & 75 & 45 & 76 & 45 \\
\hline First Stage & Avexpr & Avexpr & ICRGlaword & ICRGlaword \\
\hline Lngdp60 & $\begin{array}{l}0.37 \\
(1.33)\end{array}$ & $\begin{array}{l}0.31 \\
(0.90)\end{array}$ & $\begin{array}{l}0.28 \\
(1.58)\end{array}$ & $\begin{array}{l}0.49 \\
(2.05)\end{array}$ \\
\hline Lpop60 & $\begin{array}{l}-0.05 \\
(-0.44)\end{array}$ & $\begin{array}{l}0.05 \\
(0.40)\end{array}$ & $\begin{array}{l}-0.14 \\
(-1.89)\end{array}$ & $\begin{array}{l}-0.04 \\
(-0.47)\end{array}$ \\
\hline Col_frspport & $\begin{array}{l}-0.68 \\
(-1.94)\end{array}$ & $\begin{array}{l}-1.21 \\
(-2.97)\end{array}$ & $\begin{array}{l}-0.50 \\
(-2.17)\end{array}$ & $\begin{array}{l}-0.97 \\
(-3.44)\end{array}$ \\
\hline Col_other & $\begin{array}{l}-0.05 \\
(-0.0)\end{array}$ & $\begin{array}{l}0.96 \\
(0.70)\end{array}$ & $\begin{array}{l}0.18 \\
(0.38)\end{array}$ & $\begin{array}{l}0.27 \\
(0.28)\end{array}$ \\
\hline Euro1900 & $\begin{array}{l}0.02 \\
(1.71)\end{array}$ & $\begin{array}{l}0.02 \\
(2.92)\end{array}$ & $\begin{array}{l}0.01 \\
(1.14)\end{array}$ & $\begin{array}{l}0.02 \\
(3.14)\end{array}$ \\
\hline Constant & $\begin{array}{l}4.60 \\
(1.68)\end{array}$ & $\begin{array}{l}3.68 \\
(1.06)\end{array}$ & $\begin{array}{l}3.19 \\
(1.77)\end{array}$ & $\begin{array}{l}0.18 \\
(0.08)\end{array}$ \\
\hline R-squared & 0.1421 & 0.4464 & 0.1790 & 0.5743 \\
\hline
\end{tabular}

Note: t-statistics in parentheses. 
Table 11: Ranking of the fifteen ex-colonies with the lowest and the highest enforcing contracts procedure index. Normalized between 1-100

\begin{tabular}{|l|l|l|l|}
\hline Countryname & Enfcontproc & Countryname & enfcontproc \\
\hline Cameroon & 100 & Australia & 18.96 \\
\hline Sierra Leone & 100 & Tunisia & 24.13 \\
\hline Egypt & 94.82 & Uganda & 25.86 \\
\hline Laos & 91.37 & Malawi & 27.58 \\
\hline United Arab Emirates & 91.37 & Hong Kong & 27.58 \\
\hline Chad & 89.65 & Zambia & 27.58 \\
\hline Kuwait & 89.65 & United States & 29.31 \\
\hline Congo, Dem. Rep. & 87.93 & Canada & 29.31 \\
\hline Burundi & 87.93 & Sri Lanka & 29.31 \\
\hline Lesotho & 84.48 & Morocco & 29.31 \\
\hline Algeria & 84.48 & Nicaragua & 31.03 \\
\hline Benin & 84.48 & Jamaica & 31.03 \\
\hline Syrian Arab Rep. & 82.75 & New Zealand & 32.75 \\
\hline Angola & 81.03 & Bhutan & 34.48 \\
\hline Congo, Rep. & 81.03 & Tanzania & 36.20 \\
\hline
\end{tabular}

Table 12. Contracting institutions and civil wars. Logit and IV-2SLS analysis. (The index has been standardized between 0 and 1)

\begin{tabular}{|c|c|c|c|c|c|c|c|c|}
\hline & PRIOCW & PRIOCW & PRIOCW & PRIOCW & PRIOCW & PRIOCW & PRIOCW & PRIOCW \\
\hline & $\begin{array}{l}\text { All } \\
\text { sample } \\
\text { OLS }\end{array}$ & $\begin{array}{l}\text { All } \\
\text { Sample } \\
\text { OLS }\end{array}$ & $\begin{array}{l}\text { Ex- } \\
\text { colonies } \\
\text { OLS }\end{array}$ & $\begin{array}{l}\text { Ex- } \\
\text { colonies } \\
\text { OLS }\end{array}$ & IV & IV & IV & IV \\
\hline & (3) & (4) & (1) & (2) & (5) & (6) & (7) & (8) \\
\hline enfcontcont & $\begin{array}{l}4.38 \\
(3.99)\end{array}$ & $\begin{array}{l}5.87 \\
(3.69)\end{array}$ & $\begin{array}{l}3.79 \\
(2.50)\end{array}$ & $\begin{array}{l}0.06 \\
(3.15)\end{array}$ & $\begin{array}{l}1.42 \\
(3.00)\end{array}$ & $\begin{array}{l}1.74 \\
(4.06)\end{array}$ & $\begin{array}{l}1.22 \\
(2.29)\end{array}$ & $\begin{array}{l}1.86 \\
(3.76)\end{array}$ \\
\hline Lngdp60 & & $\begin{array}{l}-0.85 \\
(-2.62)\end{array}$ & & $\begin{array}{l}-0.78 \\
(-2.00)\end{array}$ & & & $\begin{array}{l}-0.12 \\
(-1.72)\end{array}$ & $\begin{array}{l}-0.05 \\
(-0.87)\end{array}$ \\
\hline Lpop60 & & $\begin{array}{l}0.41 \\
(1.54)\end{array}$ & & $\begin{array}{l}0.72 \\
(2.30)\end{array}$ & & & $\begin{array}{l}0.07 \\
(1.85)\end{array}$ & $\begin{array}{l}0.10 \\
(2.72)\end{array}$ \\
\hline Constant & $\begin{array}{l}-2.16 \\
(-3.71)\end{array}$ & $\begin{array}{l}-2.72 \\
(-0.67)\end{array}$ & $\begin{array}{l}-1.18 \\
(-1.46)\end{array}$ & $\begin{array}{l}-7.39 \\
(-1.42)\end{array}$ & $\begin{array}{l}-0.05 \\
(-0.19)\end{array}$ & $\begin{array}{l}-0.29 \\
(-1.19)\end{array}$ & $\begin{array}{l}-0.10 \\
(-0.10)\end{array}$ & $\begin{array}{l}-1.56 \\
(-1.88)\end{array}$ \\
\hline $\mathrm{N}$ & 145 & 105 & & 78 & 66 & 83 & 64 & 77 \\
\hline R.squared & $0.1040)$ & 0.2622 & 0.0891 & 0.2555 & & & & \\
\hline First Stage & & & & & $\begin{array}{l}\text { Enfcontpr } \\
\text { oc }\end{array}$ & $\begin{array}{l}\text { enfcontpr } \\
\text { oc }\end{array}$ & $\begin{array}{l}\text { enfcontpr } \\
\text { oc }\end{array}$ & $\begin{array}{l}\text { enfcontpr } \\
\text { oc }\end{array}$ \\
\hline Lngdp60 & & & & & & & $\begin{array}{l}-0.08 \\
(-2.10)\end{array}$ & $\begin{array}{l}-0.01 \\
(-0.27)\end{array}$ \\
\hline Lpop60 & & & & & & & $\begin{array}{l}0.004 \\
(0.26)\end{array}$ & $\begin{array}{l}-0.003 \\
(-0.17)\end{array}$ \\
\hline Legor_fr & & & & & $\begin{array}{l}0.20 \\
(3.97)\end{array}$ & $\begin{array}{l}0.18 \\
(4.56)\end{array}$ & $\begin{array}{l}0.22 \\
(4.17)\end{array}$ & $\begin{array}{l}0.19 \\
(4.46)\end{array}$ \\
\hline $\begin{array}{l}\text { LnACmortal } \\
\text { ity }\end{array}$ & & & & & $\begin{array}{l}0.02 \\
(0.87)\end{array}$ & & $\begin{array}{l}-0.02 \\
(-0.62)\end{array}$ & \\
\hline Euro1900 & & & & & & $\begin{array}{l}-0.002 \\
(-2.67)\end{array}$ & & $\begin{array}{l}-0.002 \\
(-1.34)\end{array}$ \\
\hline Constant & & & & & $\begin{array}{l}0.36 \\
(4.03)\end{array}$ & $\begin{array}{l}0.50 \\
(15.11)\end{array}$ & $\begin{array}{l}0.99 \\
(2.14)\end{array}$ & $\begin{array}{l}0.60 \\
(1.57)\end{array}$ \\
\hline R-squared & & & & & 0.2642 & 0.2643 & 0.3113 & 0.2773 \\
\hline
\end{tabular}

Note: z-statistics and t-statistics in parentheses. 
Table 13: Robustness check to consider per capita income Endogenous.

\begin{tabular}{|c|c|c|c|c|c|}
\hline & PRIOCW & PRIOCW & PRIOCW & PRIOCW & PRIOCW \\
\hline & $(1)$ & (2) & (3) & (4) & (5) \\
\hline Avexpr & & $\begin{array}{l}-0.08 \\
(-2.39)\end{array}$ & $\begin{array}{l}-0.41 \\
(-2.76)\end{array}$ & & \\
\hline Laword & & & & $\begin{array}{l}-0.15 \\
(-3.04)\end{array}$ & $\begin{array}{l}-0.40 \\
(-3.92)\end{array}$ \\
\hline Lngdp60 & $\begin{array}{l}-0.29 \\
(-4.02)\end{array}$ & $\begin{array}{l}-0.17 \\
(-1.69)\end{array}$ & $\begin{array}{l}0.27 \\
(1.20)\end{array}$ & $\begin{array}{l}-0.13 \\
(-1.30)\end{array}$ & $\begin{array}{l}0.12 \\
(0.93)\end{array}$ \\
\hline Lpop60 & $\begin{array}{l}0.09 \\
(3.41)\end{array}$ & $\begin{array}{l}0.05 \\
(1.90)\end{array}$ & $\begin{array}{l}0.08 \\
(1.64)\end{array}$ & $\begin{array}{l}0.05 \\
(1.99)\end{array}$ & $\begin{array}{l}0.05 \\
(1.59)\end{array}$ \\
\hline Constant & $\begin{array}{l}1.31 \\
(1.79)\end{array}$ & $\begin{array}{l}1.66 \\
(2.00)\end{array}$ & $\begin{array}{l}0.25 \\
(0.22)\end{array}$ & $\begin{array}{l}1.30 \\
(1.68)\end{array}$ & $\begin{array}{l}0.38 \\
(0.44)\end{array}$ \\
\hline $\mathrm{N}$ & 93 & 79 & 79 & 80 & 80 \\
\hline First stage & Lngdp60 & Lngdp60 & Lngdp60 & Lngdp60 & Lngdp60 \\
\hline Lpop60 & $\begin{array}{l}-0.07 \\
(-1.85)\end{array}$ & $\begin{array}{l}-0.07 \\
(-1.65)\end{array}$ & $\begin{array}{l}-0.05 \\
(-1.06)\end{array}$ & $\begin{array}{l}-0.07 \\
(-1.57)\end{array}$ & $\begin{array}{l}-0.05 \\
(-1.17)\end{array}$ \\
\hline Avexpr & & $\begin{array}{l}0.07 \\
(1.43)\end{array}$ & & & \\
\hline Laword & & & & $\begin{array}{l}0.13 \\
(1.98)\end{array}$ & \\
\hline Col_frspport & & & $\begin{array}{l}-0.17 \\
(-1.34)\end{array}$ & & $\begin{array}{l}-0.18 \\
(-1.43)\end{array}$ \\
\hline Col_other & & & $\begin{array}{l}-0.96 \\
(-3.60)\end{array}$ & & $\begin{array}{l}-0.96 \\
(-3.64)\end{array}$ \\
\hline Euro1900 & $\begin{array}{l}0.02 \\
(8.49)\end{array}$ & $\begin{array}{l}0.02 \\
(6.46)\end{array}$ & $\begin{array}{l}0.02 \\
(8.18)\end{array}$ & $\begin{array}{l}0.02 \\
(6.02)\end{array}$ & $\begin{array}{l}0.02 \\
(8.20)\end{array}$ \\
\hline Landlocked & $\begin{array}{l}-0.54 \\
(-3.21)\end{array}$ & $\begin{array}{l}-0.52 \\
(-2.35)\end{array}$ & $\begin{array}{l}-0.60 \\
(-2.91)\end{array}$ & $\begin{array}{l}-0.57 \\
(-2.64)\end{array}$ & $\begin{array}{l}-0.61 \\
(-2.96)\end{array}$ \\
\hline Constant & $\begin{array}{l}8.01 \\
(13.55\end{array}$ & $\begin{array}{l}7.63 \\
(9.91)\end{array}$ & $\begin{array}{l}7.78 \\
(11.51)\end{array}$ & $\begin{array}{l}7.62 \\
(10.42)\end{array}$ & $\begin{array}{l}7.85 \\
(11.87)\end{array}$ \\
\hline R-squared & 0.5082 & 0.5228 & 0.5854 & 0.5318 & 0.5844 \\
\hline First Stage & & & avexpr & & Laword \\
\hline Lpop60 & & & $\begin{array}{l}-0.05 \\
(-0.49)\end{array}$ & & $\begin{array}{l}-0.11 \\
(-1.58)\end{array}$ \\
\hline Col_frspport & & & $\begin{array}{l}0.03 \\
(5.18)\end{array}$ & & $\begin{array}{l}-0.80 \\
(-3.76)\end{array}$ \\
\hline Col_other & & & $\begin{array}{l}-0.83 \\
(-2.71)\end{array}$ & & $\begin{array}{l}-0.20 \\
(-0.44)\end{array}$ \\
\hline Euro1900 & & & $\begin{array}{l}-0.49 \\
(-0.76)\end{array}$ & & $\begin{array}{l}0.025 \\
(6.17)\end{array}$ \\
\hline Landlocked & & & $\begin{array}{l}-0.61 \\
(-1.24)\end{array}$ & & $\begin{array}{l}0.02 \\
(0.07)\end{array}$ \\
\hline Constant & & & $\begin{array}{l}7.28 \\
(4.45)\end{array}$ & & $\begin{array}{l}4.85 \\
(4.36)\end{array}$ \\
\hline R-squared & & & 0.3330 & & 0.4007 \\
\hline
\end{tabular}

Note: t-statistics in parentheses. 